\title{
A poster presentation as an evaluation method to facilitate reflective thinking skills in nursing education
}

\author{
MM Chabeli, Nursing Science Department, RAU
}

\section{Abstract}

This article seeks to establish whether the poster presentation of a specific theme can facilitate the student's thinking skills in nursing education. A qualitative, exploratory, descriptive and contextual research design where twenty students volunteered to take part in the study by signing an informed consent was followed. Descriptive naive sketches were used for data collection followed by individual interviews to validate the findings. Data was analysed by means of the descriptive method of open coding of Tesch (in Creswell, 1994:155). DENOSA's ethical standards for research (1998:7) were considered.

The findings indicated both positive and negative perceptions. The positive perceptions were: a poster presentation as an evaluation method facilitates creative, critical and reflective thinking skills; group work facilitates student participation; it facilitates problem solving skills; it increases the student's independence and a sense of ownership; and the evaluation is fair. The negative perceptions were that there was a lack of clarity on the student's expectations and that group activity is difficult. Trustworthiness was maintained in accordance with Lincoln and Guba's principles (1985:290-327). It is concluded that a poster presentation, used effectively as an evaluation method, can facilitate the learner's critical and reflective thinking skills. It is recommended that other learner-centred methods of assessment and evaluation be researched for their effective use in facilitating the higher order thinking skills of learners.

\section{Opsomming}

Hierdie artikel wil bepaal of plakkaataanbieding van " $n$ spesifieke tema 'n student se denkvaardighede in verpleegkunde kan fasiliteer. ' $n$ Kwalitatiewe, ondersoekende, beskrywende en kontekstuele navorsingsontwerp is gebruik. Twintig studente het met ondertekening van oorwoe toestemming in die studie deelgeneem. Beskrywende naiewe sketse is vir datainsameling gebruik en is opgevolg met individuele onderhoude om bevindinge toe staaf. Data is deur middel van Tesch (in Creswell, 1994:155) se beskrywende metode van opekodering ontleed. Die etiese navorsing-standaarde van DENOSA (1998:7) is toegepas.

Bevindinge het beide positiewe en negatiewe persepsies aangedui. Positiewe persepsies was: plakkaataanbieding as evalueringsmetode fasiliteer kreatiewe, kritiese en reflektiewe denkvaardighede;groepwerk fasiliteer studentedeelname; dit fasiliteer probleemoplossingsvaardighede, verhoog die student se onafhanklikheid en sin van eienaarskap; evaluering is billik. Negatiewe persepsies was dat daar 'n gebrek aan duidelikheid is van die student se verwagtinge en dat groepaktiwiteit moeilik is. Geloofwaardigheid is gehandhaaf ooreenkomstig die beginsels van Lincoln en Guba (1985:290-327).

Daar is tot gevolgtrekking gekom dat plakkaataanbieding wat doeltreffend as metode van evaluering aangewend word, 'n leerder se kritiese en reflektiewe denkvaardighede kan fasiliteer. Daar word aanbeveel dat ander leerdergesentreerde metodes van waardering en evaluering nagevors word vir die doeltreffende aanwending daarvan met die fasilitering van hoervlak denkvaardighede van leerders.

\section{Introduction}

Guidelines for a poster presentation were described in a bigger study in which a model to facilitate reflective thinking was developed. As part of the implementation of the guidelines of the model, post-basic students undertaking a degree course in nursing education were given a group assignment using a poster as an evaluation method to disseminate a newly developed curriculum effectively. It was the first time that these students were exposed to this type of evaluation. After submission of the assignments, all the students were requested to describe their perceptions with regard to a poster presentation as an evaluation method that facilitates higher-order thinking skills, the aim being to ensure quality nursing education.

The current education system in South Africa is such that there is an outcry for the provision of quality assurance in the education system of the country in line with international standards. The South African Qualifications Authority Act (Act no 58 of 1995), the National Qualification Framework, The South African Nursing Council (1999) and the Outcomes- 
Based Education approach to education and training are responsible for maintaining and ensuring quality education in nursing.

Central to quality assurance in the education and training of students is "how the students learn". The teaching and evaluation methods should facilitate critical and reflective thinking of learners in order to improve practice. Education and training should focus on service, what the National Plan for Higher Education (2001) refers to as service learning or education for service. Educators are urged to implement various methods of teaching and evaluation that promote learning such as, a poster presentation to facilitate critical and reflective thinking skills. Rote learning through structured lecture methods should be regarded as past history or used minimally where necessary.

The ideal critical thinker, according to the American Philosophical Association (1990), is habitually inquisitive, well informed, trustful, reasoning, open-minded, flexible, fairminded in evaluation, honest in facing personal biases, prudent in making judgements, willing to reconsider, clear about issues, orderly in complex matters, diligent in seeking relevant information, reasonable in the selection of criteria, focused on enquiry, and persistent in seeking results that are as precise as the subject and circumstances of the enquiry permit. On the other hand, reflective thinking is, according to Chabeli (2001:107), a rational, progressive cyclical interactive mental process, influenced by cognitive and affective thinking skills. It is triggered by uncertainty in a specific situation bringing about a state of mental awareness and disequilibrium, which leads to an interactive constructing process resulting in new insight and a changed perspective to improve practice.

Based on the two definitions, it becomes clear that there is no longer room for lip-service but action to facilitate the critical and reflective thinking of learners. The need to improve health care services is great as evidenced by the increasing mal practice described in the media. The facilitation of critical and reflective thinking of students will provide the answer to this problem only if we 'put the learnes first' and focus on their learning needs, states the then minister of education, $S$. Bhengu, in the White Paper on Education and Training (1995).

Presently, the researcher (eleven years of experience in teaching students at university level) has observed that the students are teacher dependent. They actually demand the rote learning teaching and evaluation methods that result in poor performance, especially in abstract courses that demand critical and reflective thinking, such as research methodology. The teacher who uses a lecture method is "structured, organised and good" and therefore liked by the students. The one who uses reflective teaching methods that require interaction will not be liked by the students because the students expend great energy trying to figure out the teacher's intentions (Costa, 1989:10).

The implementation of teaching and evaluation methods that will facilitate critical and reflective thinking will promote the problem-solution skills of the learners. The research ques- tion of the study is: Does a poster presentation as an evaluation method facilitate critical and reflective thinking in nursing education? What recommendations could be made to improve the existing guidelines for the effective implementation of this method of evaluation? The purpose of this study is to describe the perceptions of the students who were subjected to a poster presentation as an evaluation method to facilitate critical and reflective thinking skills, with the aim of describing guidelines for the effective implementation of this method of evaluation. The purpose will be realised through the following objectives:

- To describe the perceptions of students after the implementation of a poster presentation as an evaluation method to facilitate critical and reflective thinking in nursing education.

To describe guidelines for the effective use of poster presentations in nursing education.

\section{Underlying theoretical assumption}

Constructivist epistemology challenges traditional pedagogy in that it does take into account what individual students have learned and how they have learned it. It is also cognizant of many factors associated with contextual and meaningful learning, and learning with understanding. For constructivists, learning is not knowledge written on, or transplanted to, a person's mind as if the mind were a blank slate waiting to be written on or an empty gallery waiting to be filled (Cobern in Peters, 2000:167). They believe in the epistemological view that knowledge is built by individuals. New knowledge is built on existing knowledge, on what the student already knows from previous experiences (Shuell, 1986:412). The learning process is an active one. Learners challenge their comprehension as a result of new learning encounters.

In essence, constructivistic approach to teaching and learning is mediatory in nature (Cobern in Peters, 2000: 167). A constructivist teacher works as the interface between the curriculum and the student to bring the two together in a way that is meaningful to the learner. The idea that students discover and construct meaning from their environments suggests a rethinking by teachers about how they could teach. A constructivist teacher is one who designs learning experiences that are active, where the learners are "doing," reflecting on and evaluating their learning experiences to construct new knowledge and meaning (Yager, 1991:53). It is on this theoretical assumption that this study is based. The process of designing a poster in order to meet a specific learning outcome requires active participation that is creative, critical and reflective in nature to build and develop new knowledge, insight and perspective with regard to the given theme through interaction.

\section{Definitions of concepts}

\section{Poster}

A poster is normally a square or rectangular piece of fairly strong paper or hardboard on which information is visually displayed in a meaningful and orderly way. The purpose of a poster is to draw attention, elicit interest and create a gener- 
ally enjoyable learning environment. It motivates the learner and assists the unlocking of the content. A poster should be aesthetically inviting and instructive (Van der Merwe, 2001:5).

\section{Evaluation method}

Evaluation is a process whereby information obtained through assessment is interpreted to make judgements about the learners' competence. It is a process of determining the merit, worth or value of a process or the product of that process (Mellish; Brink \& Paton 1998:224; Gravett, 2000:2; Van der Horst \& McDonald, 1997:169).

\section{The student}

A person undergoing a post-basic degree majoring in nursing education, nursing management and a chosen speciality, registrable with the South African Nursing Council in a university in Gauteng.

\section{Reflective thinking}

Reflective thinking is a rational, progressive cyclical interactive mental process, influenced by cognitive and affective thinking skills. It is triggered by uncertainty in a specific situation, bringing about a state of mental awareness and disequilibrium which leads to an interactive constructing process, followed by the creation of new insight and a changed

\section{Nursing education}

Nursing education is the process whereby students are guided, assisted and provided with means that enable them to learn the art and science of nursing so that they can apply it to the nursing care of people who need such care (Mellish et al 1988:7). The ultimate goal of nursing education is the production of a highly skilled professional practitioner with analytical and critical thinking skills at the first level, which is that of registered nurses, registered with the South African Nursing Council.

\section{Research design and method}

A qualitative approach was used because it would be more effective to explore and describe the perceptions of students with regard to a poster presentation as an evaluation method to facilitate critical and reflective thinking within the context of nursing education (Burns \& Grove, 1993:28-29; Mouton \& Marais, 1990:204).

\section{Data collection method}

Descriptive naïve sketches were used for data collection (Giorgi in Omery 1983:52) followed by individual interviews to validate the data and the findings. This method requires

\section{Table 1: Perceptions of students with regard to a poster presentation as an evaluation method to facilitate critical and reflective thinking skills}

\begin{tabular}{|l|ll|}
\hline Category & \multicolumn{1}{|c}{ Sub-category } \\
\hline Positive Perceptions & $\bullet$ Facilitates creative, critical and reflective thinking skills \\
& $\bullet \quad$ Group work facilitates learner participation \\
& $\bullet$ Facilitates problem-solving skills \\
& $\bullet \begin{array}{l}\text { Increases learner's independence and a sense of ownership } \\
\end{array}$ & $\bullet$ Evaluation is fair \\
\hline Negative Perceptions & $\bullet$ Lack of clarity on learner's expectation \\
& $\bullet \quad$ Group activity is difficult \\
\hline
\end{tabular}

perspective (Chabeli, 2001:107). A reflective thinker will demonstrate dispositions such as self-awareness, openmindedness, enthusiasm, genuine interest, empathy, respect, trust, courage, commitment, perseverance, justice, responsibility and accountability (Dewey, 1933:16,30; Atkins \& Murphy, 1993:1190 and Palmer; Burns \& Bulman 1994:103). the researcher to allow, without bias, the perceptions of participants to unfold as they exist for the subject. Helpful clarification by the researcher is discouraged so that the resulting description will be a true reflection of the participants' perceptions. Giorgi (in Omery 1983:52) indicates that because of the detail of the completc description, the sample is usu- 
ally small. The participants were asked to complete naïve sketches on how they perceived a poster presentation as an evaluation method to facilitate their critical and reflective thinking skills, and what recommendations they would make for the description of guidelines on the effective use of a poster presentation to facilitate critical and reflective thinking skills. Field notes were taken to describe the dynamics and the researcher's impressions, and to obtain supportive information for the collected data (Wilson, 1989:343).

Of the population of thirty nursing students undertaking a post-basic degree in nursing, twenty students voluntarily participated in the study. The other ten students did not attend classes on the relevant day. All the participants belonged to the five groups that designed the posters on a specific theme as their assignment for the semester. Fifteen black students were subjected to this form of evaluation for the first time. Five white students were conversant with the method. The participants gave a written informed consent and their anonymity and the confidentiality of the data were ensured. No time limit was placed. The participants were given enough folio paper. No disturbance was envisaged as it was far from telephones. All the participants were in the same venue and started at the same time. In forty minutes, all the participants had completed the naïve sketches. They were requested not to identify themselves in any way, nor to write the name of the institution, but to feel free to describe their perceptions on the topic.

\section{Data analysis}

The data was analysed by means of the descriptive method of analysis by Tesch (in Creswell, 1994:155). Both the researcher and an independent coder, who was purposively selected, analysed the data by using Tech's protocol and held a consensus discussion meeting after one week to agree on the categories and sub-categories. To increase the credibility of the study, five students who were participants were purposively selected for individual interviews to validate the categories and subcategories. Following the completion of the data analysis, a literature control was done to recontextualise the data within the existing theoretical framework (Morse \& Field, 1996:106). Trustworthiness was maintained by using strategies of credibility, applicability, dependability and confirmability as described by (Lincoln \& Guba 1985:290-327).

\section{Results and discussion of the results}

Two main categories with sub-categories with regard to the perceptions of the students emerged as positive and negative perceptions of a poster presentation as an evaluation method to facilitate critical and reflective thinking in nursing education. The categories and sub-categories from the data analysed are presented in table 1 .

\section{Positive perceptions Facilitates creative, critical and reflective thinking skills}

All the participants acknowledged the fact that a poster pres- entation facilitates creative, critical and reflective thinking skills- "It was stimulating; a good critical thinking exercise indeed because we had to debate and argue in order to explore different components of the topic. We had to analyse and interpret the information, be creative in order to come up with striking, yet meaningful important aspects to be included in the poster". Yet another citation: "This assignment improved our analytical and critical thinking. We were reflecting on our past experience about the theme. I understood better than when I had to write an assignment on my own".

It is indicated in the literature that critical thinkers are habitually inquisitive, prudent in making judgements, willing to consider, clear about issues, orderly in complex matter, diligent in seeking relevant information, reasonable in the selection of criteria, focused on enquiry and persistent in seeking results that are as precise as the subject and circumstances of the enquiry permit (American Philosophical Association 1990). Beyer $(1988: 64,65)$ argues that both critical and reflective thinking are creative in nature. Critical thinking is evaluative in that it involves the precise, persistent and objective analyses of any claim, source or belief. It seeks to judge its accuracy, validity or worth. Reflective thinking is deliberative and divergent in nature, and seeks to generate new insight and a changed perspective in relation to the existing conception.

Critical thinking operations are more complex and are distinguished by argument making and argument analysis in order to evaluate the worth and accuracy of a claim. However, both thinking skills are supported by affective thinking skills such as willingness, open-mindedness, self-awareness, respect, trust, courage, commitment, honesty, flexibility, enthusiasm, empathy, responsibility and accountability (Dewey, 1933:16,70; Atkins \& Murphy, 1993:1190; and Palmer et al 1994:108).

The first critical learning outcome of the South African Qualifications Authority Act (Act 58 of 1995:5) requires the learner to use critical and creative thinking skills, to organise and manage themselves and their activities responsibly and effectively, and to collect data, and analyse, organise and critically evaluate information. SAQA's critical learning outcomes serve as a guide and a challenge to both the teacher and the learner to use teaching and evaluation methods that are learner centred. A poster presentation has been tested and proved to be one of the methods that could facilitate the learner's thinking skills.

Indeed, the students diligently seek relevant information about the topic, be reasonable in selecting the significant criteria for inclusion in the poster, be focused on enquiry and persistent in seeking the results that were as precise as the topic permitted, as evidenced by: "We really had to think; it was the first time to do something like this, but we had to show insight into the learning content by putting only important aspects of the topic on a hardboard meaningfully and attractively". The debate and arguments to justify their decisions as to what is to be included facilitated the students' thinking skills and thus learning took place. Both the cognitive and affective activities that took place to facilitate thinking and learning will improve the guidelines for the implementation of this method of evaluation. 


\section{Group work facilitates learner participation}

The participants perceived group work as one of the important strategies that facilitate critical thinking in that it encourages co-operative, shared and collaborative learning as evidenced by: "It was good working in a group, getting different ideas and filtering out until you have the best idea. We learnt how to work together in a group, reflecting and using past experiences; it was exciting and stimulating, and it was a true learning experience". The participants were also of the opinion that group work facilitates interaction and promotes human relations, as cited: "Group interaction promotes human relations in that there is that respect of other members' ideas and opinions as well as a trusting relationship". One participant added: "Group dynamics apply and empathetic understanding is developed. We had to tolerate each other regardless of race and gender. Group work does promote learning. You gain knowledge and skills from other students through active participation".

Group work or team work is at the centre of outcomes-based education. The second critical learning outcome (SAQA, 1995:8) requires learners to work effectively with others as members of a team, group, organisation and community. Teachers are required to reflect on, and explore a variety of strategies to facilitate critical thinking and effective learning.

Active participation, interaction, discourse, collaboration, sharing of ideas, availability of resources, trust and respect through team work are integral to the process of facilitating critical and reflective thinking in clinical nursing education, state (Reilly \& Oerman 1985:41,44,77). Van der Horst \& McDonald (1997:27) argue that no reflective thinking will ever be facilitated if the learners are passive recipients of knowledge using rote-learning methods. Reflective thinking demands interaction as an underlying dynamic by employing learner-centred methods of teaching and evaluation where students are required to justify their decisions and actions through argumentation (Chabeli 2001:190).

The outcomes-based education approach enforces the active participation of learners in order to facilitate critical and reasoning skills. It encourages teachers to use group work or teamwork constantly to consolidate knowledge from past experiences, and to interpret learning situations meaningfully (Van der Horst \& McDonald 1997:27). The participants stated: "Group assignment puts learners in a situation where they have to work together, take a lead in some instances to make one's stand known".

From the arguments by the participants as evidenced by literature, it becomes clear that a poster presentation does facilitate the critical and reflective thinking of learners through group interaction where discourse, co-operation, collaboration, sharing of ideas, respect, trust, and willingness of learners takes place.

\section{Facilitates problem-solving skills}

With regard to poster presentations facilitating the student's problem-solving skills, the participants stated: "As you engage in debate, you argue and learn to justify and support your view's and opinions with regard to the topic. You analyse the situation critically and learn to prioritise facts in a meaningful sequence. Thereafter, you are able to evaluate the outcome. In that way problems are solved amicably".

Problem solving requires one to take time to collect data, weigh facts and think the matter through. Problem solving cannot occur by jumping to conclusions; one needs to understand an idea (Kozier; Erb \& Blair, 1997:224). Nurses who think in a rational, purposeful manner use logical reasoning in the decision-making and problem-solving process in order to improve practice. This means, according to Botes, (2000:29), that they can justify their decisions on rational grounds.

Concerning logical reasoning and argumentation, Dewey $(1933: 133,232)$ is of the opinion that without reasoning skills, no reflective activity will take place. Instead ideas, meanings and facts would heap up like grains of sand. The meaningful construction of knowledge should be done through discourse and the diaiogic mode of teaching and learning. As the participants indicated: "Poster presentations require learners to work collaboratively in order to share ideas and thoughts, to interpret and justify their decisions responsibly, based on the existing evidence". To justify is to show justice or adequate ground for the truth (Little Oxford Dictionary 1986).

An effective poster presentation will be facilitated if learners engage in the critical analysis and synthesis of information, and use their creative imagination and make inferences in order to draw conclusions as to what content is to be included in the poster to make it meaningful and attractive. Creativity involves the application of knowledge, imagination and judgement to problem solving. It is guided and driven by the desire to seek the original. It feeds on flexibility and honours diversity (Beyer 1988:297). Teaching learners to be creative and imaginative in order to improve their critical and reflective thinking skills remain a challenge to facilitators (Chabeli 2001:200).

\section{Facilitates the student's independence and a sense of ownership}

The participants perceived a poster presentation as an evaluation method that increases their independence and a sense of ownership: "A poster presentation as a group assignment was exciting, stimulating and a true learning experience with fun. Everybody in a group was willing to share ideas and was ready to learn. It was a real challenge, and a positive experience. Surely, we can do it better next time because now we know what is expected. It was much more fun than a test though". 
Referring to the principles of poster presentations, the participants indicated: "Now I know the principles of a poster presentation: that it must be clear, neat, big, colourful and striking to attract the reader. It was interesting that we were able to identify our strengths and weaknesses, to feel that you own your work, you are independent. What was even more challenging was to be given an opportunity to defend our poster and state the reason why certain information was included in the poster. This was a real challenge as we dialogued with a panel of evaluators. It made us feel good and it was fun to feel independent and have a sense of ownership".

Indeed, the learners are expected to take responsibility for their own learning and for taking full control and monitoring their own learning activities. Slabbert (1991b:70) refers to this ability as meta-learning. Slabbert defines meta-learning as the ability of the learners to plan, execute, monitor and evaluate their own learning, and develop an awareness of their mental processes. Learners decide how learning will be achieved, they assess learning activities realistically, and are aware of their own mental or cognitive abilities, learning abilities, learning styles and learning skills. It can be concluded that a poster presentation as a method of evaluation, if adequately used, can facilitate the learner's critical and reflective thinking skills as well as lifelong learning skills.

\section{Evaluation is fair}

The use of a panel of evaluators in a poster presentation was perceived by the participants as positive and fair, as cited: "However, evaluation was fair in that it was done by four evaluators, which made us feel good because the credibility of the method was increased. We recommend that poster presentations be done even next year, and most important, to be introduced to the basic training of student nurses".

To evaluate, according to Beyer (1988:334) and Vand der Horst and McDonald (1997:169), is to determine the worth, accuracy or completeness, judging, appraising and assessing the process of making a decision about the learning of the learner by using the information gained from formal and informal assessment. Evaluation answers the question "How good?" or "How well?". The principles of evaluation such as objectivity, relevance, clear criteria, validity, reliability, comprehensiveness and being propedious (leading to the acquisition of new knowledge) should be considered (Mellish et al 1998:228-229).

A poster presentation provides objectivity in that the criteria and guidelines for presentation and evaluation are provided. Inter-rater reliability is measured by using a panel of evaluators where learners are allowed to defend, argue and justify their standpoint with regard to what and why certain content was included in the poster. It is propedious in that the learners learn and grow from the evaluation.

\section{Negative perceptions Lack of clarity of the student's expectation}

Some participants expressed their negative perceptions con- cerning the lack of clarity about what was expected from them, as stated: "It seemed as if there was misunderstanding regarding how the poster had to be presented. Some students had mostly pictures while others only text. What was expected? Everybody must understand, please".

Another perception indicated: "It was difficult to actually get what was expected of us, what to actually put on the poster, whether to put more pictures than words. We did not have clear guidelines on the critical elements to be included, that is, one did not know what to expect. More explanation and examples would have helped".

As much as guidelines and the criteria for evaluation were given to all the students, because it was the first time they were exposed to this type of evaluation, some students needed more descriptive guidelines and examples from good previous posters. According to Knowles (in Mellish et al 1998:67), learners as adult learners have the right to know what is expected from them. They should be involved in decisions about their learning, encouraged to formulate their own learning objectives, identify their own learning resources and use their strategies in order to achieve their learning objectives. Knowles believes that learners should be involved in evaluating their learning, preferably through qualitative evaluation methods. A poster presentation uses the principles of adult learning in that learners take part in their own evaluation and are satisfied with the outcome of the evaluation. However, many more descriptive guidelines should be give to the student as well as a good example of a poster from previous groups.

\section{Group activity is difficult}

Some participants experienced difficulty in group activity because they felt it was time consuming especially since they lived far apart and could only meet once a week. Besides, some students dominated the group and this made some group members uncomfortable, as indicated: "Students staying at different places made it impossible to get together as a group. Some people want to run the show, so it is difficult to work in a group whose members are not co-operative. The problem was compounded by students not having any background experience in the designing of a poster. Non-participation from other group members is frustrating".

Group work and team spirit is the backbone of the outcomesbased education approach in order to facilitate critical thinking and learning (SAQA, 1995:8). OBE is increasingly gaining ground in the broader educational spheres in South Africa (Mellish et al 1998:99). Group work encourages co-operative learning and maximises team learning. Teachers should encourage group work and organise small group numbers, that is, not more than five members in a group who are heterogenous in nature to promote inter-racial socialisation (Biehler \& Snowman, 1991:257, 258, 263; Mellish et al 1998:118). Students should be allowed to choose members of the group themselves in order to avoid the negative perceptions, as indicated. Guidelines for the effective use of a poster presentation as an evaluation method to facilitate critical and reflective thinking skills will be described. 


\section{Guidelines for the effective use of a poster presentation as an evaluation method in nursing education}

Through deductive analysis and synthesis, the following guidelines were inferred in accordance with the identified themes. Technical aspects are included as they were also deduced from the study.

\section{Technical aspects}

- The purpose of a poster presentation used as an evaluation method should be clearly explained to the students. The purpose should be directed at one specific aim.

- A poster should be clear, neat, large enough, accurate, creative, comprehensive, colourful and striking to attract the reader.

\section{To facilitate critical and reflective thinking}

- First, the group members should be willing, openminded. committed, flexible, enthusiastic, responsible and accountable for their own actions.

- The group members should have an empathetic understanding, respect and a trusting relationship.

- They should diligently seek relevant information about the topic and identify the kind of evidence that would exist if the claims were true, and that should exist if the claim were untrue.

- $\quad$ They should be reasonable in selecting the significant criteria for inclusion in the poster.

- $\quad$ They should appreciate the process of argument making and argument analysis.

- They should critically analyse and interpret information through discourse and argumentation.

- They should distinguish the relevant from the irrelevant.

- They should evaluate the reasons for the inclusion of the content (accuracy, sufficiency and significance).

- They should place the information on a hardboard meaningfully and attractively.

\section{Group work facilitates learner participation}

- Encourage active participation of learners in sharing of ideas and thoughts through interaction.

- Encourage cooperative and collaborative learning.

\section{Facilitating problem-solving skills}

- Learn to identify and recognise a problem, and clarify key elements in problematic situations.

- Prioritise facts logically and meaningfully and evalu- ate the outcome.

- $\quad$ Engage in argumentation, justify and support your views and opinions based on evidence. Justify your decisions on rational grounds.

- Take time to collect information, weigh facts and consider the matter thoroughly.

- Think rationally, purposefully and use logical reasoning in the decision making and solving of problems.

- Use creative imagination and make inferences in order to draw conclusions as to what is to be included in the poster to make it meaningful.

\section{Increase the learner's independence and a sense of ownership}

- Identify and reflect on your strengths and weaknesses.

- Defend your decisions made on the poster based on evidence.

- Acknowledge your independence and a sense of ownership in your work.

\section{Fair evaluation}

- Evaluation should be objective, relevant, valid, reliable, propedious and have clearly defined criteria for evaluation.

- $\quad$ Engage in self-assessment and verbalise the assessment findings to the panel of evaluators

- Use a panel of evaluators.

\section{Consider the student's expectations}

- Involve the students in the decisions about the planning and formulation of the learning objectives with regard to the poster presentation as an evaluation method.

- $\quad$ Provide explicit and descriptive guidelines to the use of a poster as an evaluation method.

- Give learners the opportunity to defend their decisions on the inclusion of the content in the poster.

- $\quad$ Provide the students with a good example of a poster from the previous groups.

\section{Encourage group activity}

- $\quad$ Encourage participation by all group members

- Every group should elect a group leader to direct the group activities.

- Allow students to choose members of the group themselves.

- Group members should not exceed five (5).

- $\quad$ Place the emphasis on non-domination by other members of the group.

- Encourage heterogenous groups to promote inter-racial socialisation and cultural sensitivity to maximise learning. 


\section{Conclusion}

In response to the recommendation made in Chabeli's, article (2001:91), which stated that further research should be made to explore the use of alternative methods of assessment and evaluation in order to evaluate the learner's competence in nursing education, a poster presentation was used on postbasic students where their perceptions were described to establish whether it could facilitate the critical and reflective thinking of learners in nursing education. The study has revealed that a poster presentation, used effectively as an evaluation method can facilitate the learner's critical and reflective thinking. Guidelines to use posters effectively as an evaluation method are described. The participants also recommended that the strategy be used on basic students to facilitate their thinking skills.

\section{References}

AMERICAN PHILOSOPHICAL ASSOCIATION 1990: Critical thinking: A statement of expert consensus for purpose of educational assessment and instruction. ERIC Document Reproduction Service, No ED 315-423.California. American Philosophical Association.

ATKINS, S \& MURPHY, K 1993: Reflections: a review of the literature. Journal of Advanced Nursing. 18:1188-1192.

BEYER, BK 1988: Developing a thinking skill program. London: Allyn and Bacon, Inc.

BIEHLER, RF \& SNOWMAN, J 1997: Psychology Applied to Teaching. New York: Houton Mifflin Company.

BOTES, AC 2000: Critical thinking by nurses on ethical issues like the termination of pregnancies. Curationis. September 2000: 26-31.

BURNS, N \& GROVE, SK 1993: The Practice of nursing research conduct, critique and utilization. Toronto: WB Saunders Company.

CHABELI, MM 2001: A model to facilitate reflective thinking in clinical nursing education. Johannesburg: Rand Afrikaans University. (D-Cur Thesis).

CRESWELL, JW 1994: Research Design: Qualitative and Quantitative Approach. London: Sage Publication.

DEWEY, J 1933: How We Think. A Restatement of the relation of reflective thinking to the educative process. Lexington: Massachusetts.

GRAVETT, S 2000: Assessment and evaluation methods OBE. Paper presented at the Forum for University Departments of Nursing in South Africa (FUNDISA) 26-27 May 2000. Gauteng: Witwatersrand University.

KOZIER, B; ERB, G \& BLAIR, K 1997: Professional nursing practice. Concepts and perspectives. New York: AddisonWestley.
LINCOLN, YS \& GUBA, EG 1985: Naturalistic inquiry. London: Sage.

LITTLE OXFORD DICTIONARY OF CURRENT ENGLISH 1986.

MELLISH, JM; BRINK, HIL \& PATON, F 1998: Teaching and learning the practice of learning. Johannesburg: Heinemann.

MORSE, JM \& FIELD, PA 1996: Nursing research. London: Chapman \& Hall.

MOUTON, J \& MARAIS, HC 1990: Basic concepts in the methodology of the social science. Pretoria: Human Science Research Council Publishers.

OMERY, A 1983: Phenomenology: a method of nursing research. Advances in Nursing Science, January 1998: 49-63.

PALMER, AM; BURNS, S \& BULMAN, C 1994: Reflective practice in nursing. The growth of the professional practitioner. London: Blackwell Scientific Publications.

PETERS, M 2000: Does constructivist epistemology have a place in nursing education? Journal of Nursing Education. 39(4) April 2000:166-172.

REILLY, DE \& OERMAN, MH 1985: The clinical field. Its use in nursing education. Norwalk, Connecticut: Appleton.

SOUTH AFRICA (Republic) 2001: National Plan for Higher Education. Ministry of Education. Pretoria

SOUTH AFRICA (Republic) 1995: South African Qualifications Authority Act (Act 58 of 1995). Pretoria: Government Printers.

SOUTH AFRICA (Republic) 1995: White Paper on Education and Training. Government Gazette 357 (16312), Cape Town.

SOUTH AFRICAN NURSING COUNCIL 1999: Transformation of nursing education and training for basic and post-basic nursing programmes. Document A.

SHUEL, TJ. 1986: Cognitive conception of learning. Review of Educational Research. 56(4): 411-436.

SLABBERT, JA. 1991b: The training of meta-teaching teachers. Journal of Teacher Educators, 17, Winter, 70-81.

VAN DER HORST, H \& McDONALD, R 1997: OutcomesBased Education. A teacher's manual. Pretoria: Kagiso.

VAN DER MERWE, C 2001: Instructional Media (Learning Support Materials). Rand Afrikaans University: Gauteng.

WILSON, HS. 1989: Research in nursing. Califonia: Addison Wesley. 
YAGER, RE 1991: The constructivist learning model. Towards real reform in science education. The Science Teacher. 58(7):

52-57. 